\title{
THE EUROPEAN SOCIETY FOR PHILOSOPHY OF MEDICINE AND HEALTH CARE
}

c/o Dr. Bert Gordijn, Secretary of the ESPMH

Dept. of Ethics, Philosophy and History of Medicine 137 EFG

Radboud University Nijmegen Medical Centre

PO Box 9101, 6500 HB Nijmegen, the Netherlands

tel: $\quad$ 024-3615320, from abroad: $31-24-3615320$

fax: $\quad 024-3540254$, from abroad: 31-24-3540254

\section{MEMBERSHIP APPLICATION}

I would like to become a member of the European Society for Philosophy of Medicine and Health Care.

E-MAIL:

DUES(note: memberships are for the calendar year; please indicate your choice)
-FULL MEMBER $.0 \$ 40$ .040 euro
-INSTITUTIONAL MEMBER ....0 \$250 .0250 euro

METHODS OF PAYMENT (please indicate your choice):

0postal account nr 5780894 of the ESPMH, Kerkbuurt 11, 1551 AB Zaandam, the Netherlands (indicating 'ESPMH membership')

Obank account nr 370109295 of the RABO Bank (Swiftcode RABONL2U; IBAN nr. NL26RABO0370109295), Kerkstraat 2, 1551 BN Westzaan, in care of: ESPMH conference account (indicating 'ESPMH

0credit card membership').

........... ........Visa

0 American Express

Card no:

Date of expiration: 